\title{
DEVELOPING SMART TOURISM USING VIRTUAL REALITY AS A TOURISM PROMOTION STRATEGY IN INDONESIA
}

\author{
Idris IDRIS* \\ Universitas Negeri Malang, Faculty of Social Science, Social Studies program, Malang, Indonesia, e-mail: idris.fis@um.ac.id
}

\author{
Khofifatu Rohmah ADI \\ Universitas Negeri Malang, Faculty of Social Science, Social Studies program, Malang, Indonesia, e-mail: khofifatu.rohmah.fis@um.ac.id
}

Rizky FIRMANSYAH

Universitas Negeri Malang, Faculty of Economics, Accounting Department, Malang, Indonesia, e-mail: rizky.firmansyah.fe@um.ac.id

Ardhina NADHIANTY

Universitas Negeri Malang, Faculty of Social Science, Malang, Indonesia, e-mail: ardhina.nadhianty.1807416@students.um.ac.id

Mokhamad Husni MOBAROQ

Universitas Negeri Malang, Faculty of Social Science, Malang, Indonesia, e-mail: mokhamad.husni.1807416@students.um.ac.id

Pangestu Gusti PUTRI

Universitas Negeri Malang, Faculty of Social Science, Malang, Indonesia, e-mail: pangestu.gusti.1807416@students.um.ac.id

Adam Satriya PRATAMA

Universitas Negeri Malang, Faculty of Social Science, Malang, Indonesia, e-mail: adam.satriya.1807416@students.um.ac.id

Efrina Rizkya WAHONO

Universitas Negeri Malang, Faculty of Social Science, Malang, Indonesia, e-mail: efrina.rizkya.1707416@students.um.ac.id

Citation: Idris, I., Adi, K.R., Firmansyah, R., Nadhianty, A., Mobaroq, M.H., Putri, P.G., Pratama, A.S., \& Wahono, E.R. (2021). DEVELOPING SMART TOURISM USING VIRTUAL REALITY AS A TOURISM PROMOTION STRATEGY IN INDONESIA. GeoJournal of Tourism and Geosites, 35(2), 332-337. https://doi.org/10.30892/gtg.35210-656

\begin{abstract}
Technological developments have forced several sectors to adapt to technology, one of which is the tourism sector. Departing from the need for effective and efficient promotional tools in the development and marketing strategies of potential tourism destinations in Indonesia, this study aims to develop a tourism information system (SIPADU) with the concept of $\mathrm{m}$ tourism based on android using virtual reality technology. The research and development (R\&D) was used as a research method by applying ADDIE model (analysis, design, develop, implementation, and evaluation) in the development process. This study found that SIPADU, in practical terms, is feasible to be used as an effective Android-based promotional media for tourism promotion in Indonesia. In addition, the development of this product can help travelers to obtain tourist information easily and quickly, and can become a medium for sustainable tourism development.
\end{abstract}

Key words: tourist destination, SIPADU, smart tourism, android-based, promotion strategy

\section{INTRODUCTION}

Tourism is a strategic sector that is one of the largest contributors to a country's economic growth. In the world, tourism accounts for $10.4 \%$ of GDP and $9.9 \%$ of total employment. Meanwhile in ASEAN, this sector is the biggest driver of the country's economic growth, particularly in Malaysia, Singapore, Indonesia and Thailand (Manzo, 2018). Meanwhile, in Indonesia, in the list of the highest foreign exchange earners, the tourism sector ranks fourth after oil and gas, coal, and palm oil. In fact, by 2020, the tourism sector is expected to become Indonesia's main source of foreign exchange (Kemenpar, 2018). In this context, as a potential sector, tourism can open job vacancies (Kim et al., 2016; Martin et al., 2008), increase people's income (Du et al., 2016), foster a healthy investment climate (Thompson, 2011), and also can increase the economic growth of a region significantly (Garcia et al., 2015). Various efforts have been launched and implemented by the government, in this case the ministry of tourism, such as compiling a strategic national tourism area (KSPN) with 88 tourist destination areas that are made priorities for the "10 new Bali", making a visa-free visit policy (PP. No. 21 2016), promoting the Beautiful Indonesia and Generasi Wonderful Indonesia programs (Kemenpar, 2018). In addition, online promotion efforts have also been increased through social media networks and various other means, by implementing information technology systems (Fauzi, 2018). The development of increasingly sophisticated information technology currently plays a strategic role in helping to facilitate 
tourism and tourist stakeholders in obtaining actual information about tourist destinations including the facilities, accessibility and amenities provided (Borràs et al., 2014; Buhalis and Law, 2008; Kiralova and Pavliceka, 2015; Yoo et al., 2017).

The role of information technology in tourism development strategies, both in the world and in Indonesia, is recognized as the most strategic tool in increasing the effectiveness and efficiency of tourism destination promotion (Berne et al., 2012; Huang et al., 2017; Sigala, 2018; Vichivanives and Ralangarm, 2015; Xiang, 2018). Information technology is not only an instrument in the fundamental function of information and communication, but technology has also become a transformational tool in the structure and operations of the tourism industry as well as the roles and functions of tourism stakeholders (Sigala, 2018). Search for travel agents, payments, hotel reservations, and various other needs, all currently must be available in an interconnected and synchronized manner via the internet and can be accessed easily and quickly (Huang et al., 2017). Thus, smart tourism (Huang et al., 2017; Li et al., 2017) or m-tourism (Fermoso et al., 2015; Rashidi et al., 2016; Sanchez et al., 2013) which is associated with providing high accessibility in information and communication about tourism (Wang et al., 2014) a fundamental requirement for the tourism industry (Sigala, 2018). Madura is an archipelago in East Java, Indonesia which has many potential tourist destinations to be developed. Unique and different tourism characteristics, such as historical tourism, cultural tourism, religious tourism, and marine tourism which are spread across four districts in Madura, have become a significant tourist attraction for the income of the East Java government (Arifin, 2017). However, based on studies conducted (Malia and Hanafi, 2018; Nurif and Sulastri, 2017), tourism in Madura has relatively not had a significant impact on regional income and the welfare of the community around tourist sites. In addition, the use of information technology in tourism development strategies such as the concept of smart tourism is still not a strategic platform for tourism development in Madura.

There are many studies that have been conducted. Some of the relevant researches were limited to looking at development planning and tourism development strategies (Jannah and Idajati, 2018), participation of local communities and village government in supporting tourism development (Prihaariantova, 2017; Purnomo et al., 2020; Wahyuningtyas et al., 2019, 2020), and identification of economic potentials and benefits as well as the carrying capacity of coastal areas (Rini et al., 2015). Meanwhile, research related to information technology-based tourism development has also been carried out by several researchers such as the development of a Google Map or GIS-based application that makes it easier for tourists to find information on the location of tourist attractions (Anamis et al., 2017; Arifin, 2017), based on augmented reality (AR) and smart tourism which allows tourists to enjoy virtual reality and easy access to information (Huang et al., 2017; Jung et al., 2015), and based on m-tourism, which makes tourism information accessible only by using a smartphone (Fermoso et al., 2015; Kiralova and Pavliceka, 2015; Rashidi et al., 2016; Styawan, 2018; Ukpabi and Karjaluoto, 2017). However, the limited integration of the use of digital technology development based on android with the m-tourism approach by using virtual reality as a tourism promotion tool, makes this study much needed and is projected to have a significant impact both on tourism managers and for tourists. This study was conducted to fill that gap.

\section{MATERIALS AND METHODS}

This study used a research and development approach. In general, this study was divided into two phases; the first stage was a needs analysis through the identification and mapping of potential tourist destinations in four districts in Madura. At this stage, primary data collection used interview and observation instruments, with data sources consisting of tourism stakeholders in Madura such as the tourism office, investment and licensing offices, tourist destination managers, travel agent entrepreneurs, hotels, guest houses, tourists, and others. In addition, the data collection process was also carried out by involving local communities in focus group discussions. The second stage was the development of an Android-based SIPADU application using virtual reality. At this stage the system development used the ADDIE model (analysis, design, development, implementation, and evaluation) (Branch and Kopcha, 2014). ADDIE was used in various design and development of software and application (Budoya et al., 2019; Moradmand et al., 2014). The steps, at this stage, began with a needs analysis or problem identification and initial data collection as needed, then proceeded with the desired development design before building a system or product development designed in accordance with the aims and objectives of the research. The next phase, after the system developed, was product development, product validation and product tested to determine whether the product being developed was feasible or not.

After that, the product was revised based on the results of validation carried out by expert validators, before the prototype product was tested. The next phase was product implementation, in which the product was tried out on students in Universitas Negeri Malang as shadow tourists. The instrument of effectivity measurement was designed to test the system performance. The next stage was operational evaluation and revision based on previous measurement instruments and operational testing of product use to be fit for use or not. The stages can be seen in the following figure.

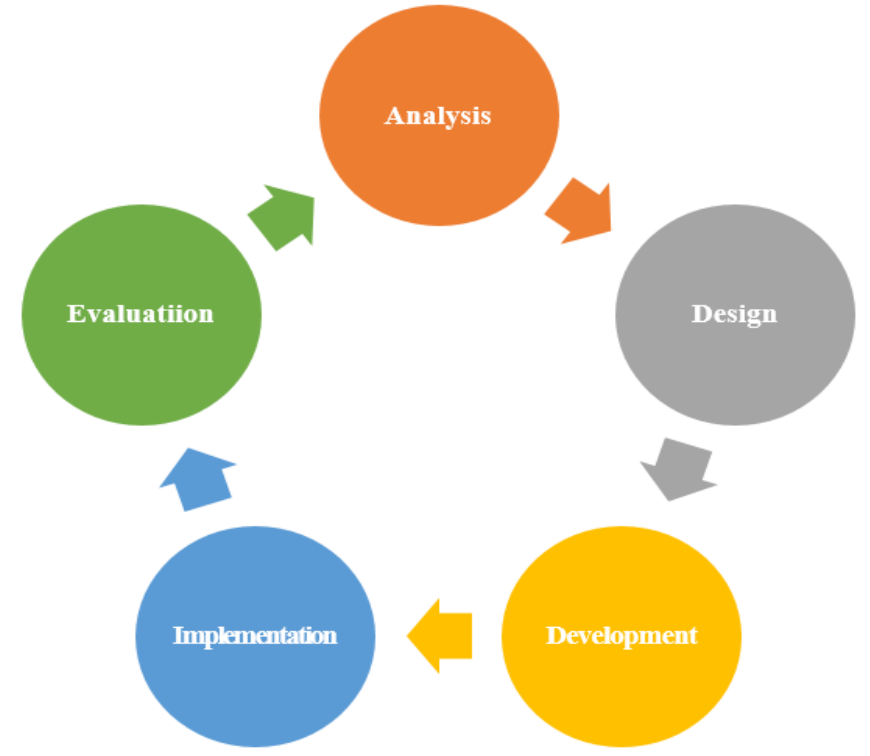

Figure 1. ADDIE model 


\section{RESULTS AND DISCUSSIONS}

\section{Analysis}

The first stage in this development is a needs analysis. Based on the reality, the existence of many tourism destinations in Madura has been developed by the government and non-governmental organizations. Tourism management is still conventional with traditional tourism promotion. Tourists do not get access to comprehensive information related to tourist attractions in Madura. In addition, the lack of information about accommodation and amenities as tourism support capacity in Madura, Indonesia makes tourists confused when they want to visit tourist destinations in Madura. Another problem, which is no less important, is that there is no strategic promotional media for tourism development. Of the four districts on the island of Madura, only one district has sufficient information about tourist destinations and access to other information, in the form of tourist websites. Thus, given the many tourism potentials that exist in Madura such as nature tourism, religious tourism, and various other forms of tourism, stakeholders have not been able to utilize and optimize information technology that is easy and effective as a medium for tourism promotion. Therefore, the development of an android-based tourism information system promotion media is expected to be one of the supporting capacities for tourism development in Madura.

\section{Design}

This application product was developed specifically to provide information to tourists from destinations, accommodation to amenities in Madura. In addition, it is hoped that this application product can be a means of promotion for the tourism industry in Madura.

Table 1. SIPADU Features

\begin{tabular}{|c|l|l|}
\hline No & Categories & \multicolumn{1}{c|}{ Features } \\
\hline 1 & Destinations & $\begin{array}{l}\text { Displaying tourist destinations in Madura ranging from natural tourism, religious tourism, culinary tours, artificial } \\
\text { tours to cultural tourism with a total of 45 destinations. }\end{array}$ \\
\hline 2 & Accommodations & Displaying accommodation such as hotels, guest houses and inns. There are 28 accommodations throughout Madura. \\
\hline 3 & Amenities & Displaying amenities such as restaurants, souvenir shops and public facilities with a total of 69 amenities. \\
\hline 4 & Application Inf. & $\begin{array}{l}\text { Displaying information about the application, the purpose for which the application was created, and some } \\
\text { application features. }\end{array}$ \\
\hline
\end{tabular}

Search, filter and maps features are available in the category of destinations, accommodation and amenities. The search column functions to search for destinations, accommodations and amenities according to the entered keywords. Then the filter functions to filter destinations, accommodations and amenities according to the selected options. Meanwhile, maps serve to change the appearance of destinations, accommodations and amenities that were originally in the form of a list to display based on places on maps. In addition, each feature is equipped with a description, address and photo in 360 form and a directions feature is available to go directly to google maps and display directions for users so that they are more interested and have a picture or more information about destinations, accommodation and amenities.

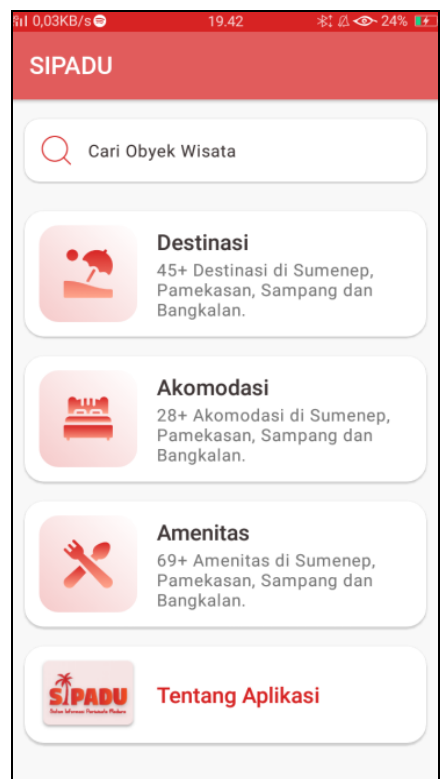

Figure 2. Menu

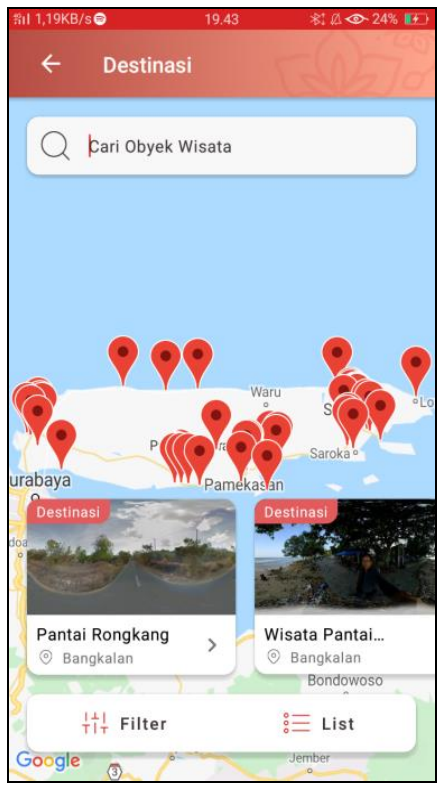

Figure 3. Search for tourism objects

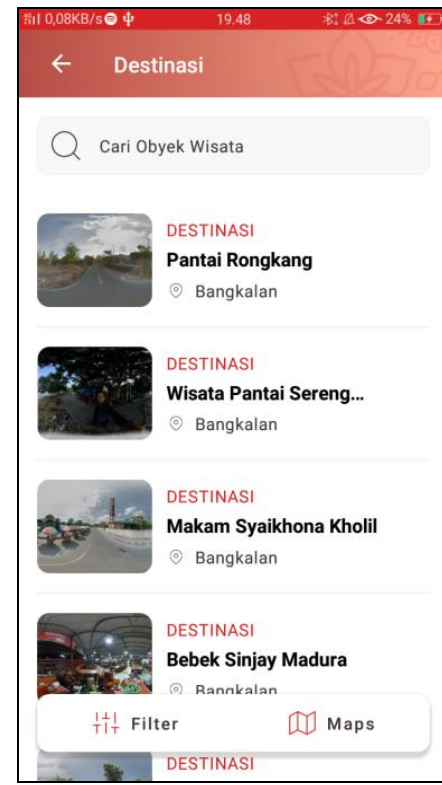

Figure 4. List of destinations

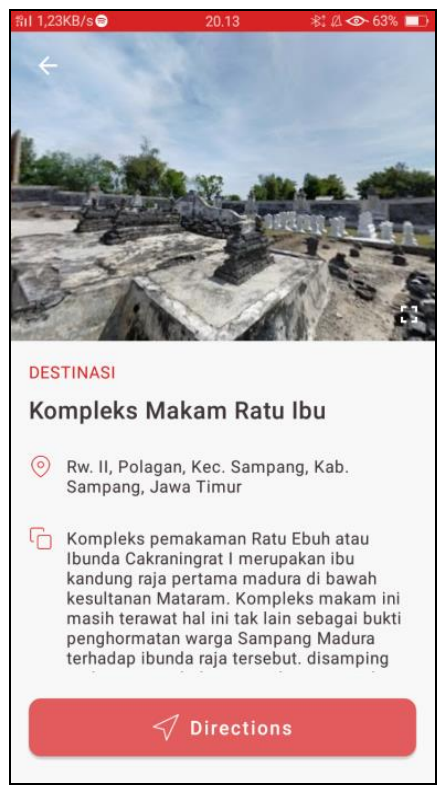

Figure 5. VR image and direction

\section{Development}

\section{Product development}

Based on the results of product development, the SIPADU application product contains several features such as the search for destinations, accommodation, and amenities. Destination search refers to seeking information about various tourist destinations that can be visited by travelers, at least 45 tourist destinations including natural tourism, artificial tourism, religious tourism, culinary tourism, and cultural tourism in Madura. Meanwhile, in the accommodation search feature, tourists 
can find 26 information about inns, hotels, guest houses and inns. In the last feature, amenities, there are 69 information provided relating to information on support for tourism facilities such as restaurants, souvenir shops, and public facilities. All of these facilities are developed with the help of virtual reality images that give a real visible effect of each destination. The results of product development can be seen in the following figures.

\section{Product Validation}

Product validation in this development was carried out by a media expert, Wahyu Djoko Sulistyo, M. Pd. Product validation was conducted to provide recommendations on whether the product being developed was feasible or not. The instruments used to measure the appropriateness of a product were related to system aspects, user aspects, and interaction aspects. In addition to validation by media experts, product validation in this development was also carried out by a linguist, Didin Widyartono, SS, M. Pd. Product validation was to provide recommendations on whether the product being developed was feasible or not. The instrument used to measure the appropriateness of the product being used includes the physical size of the application, logo design, cover typography, content illustration, application content layout, and application content typography. According to the results of product validation by experts, in general, it can be concluded that the product developed can be tested or implemented. The validation instrument was measured using a Likert four scale with a range of 1-4 $(1=$ Very Bad, $2=$ Bad, $3=$ Good, and 4 = very good $)$. The results of the expert's validation can be seen in the table 2 .

Table 2 shows that the results of the evaluation of media experts generally assess that the products developed are in the good category. This is indicated by the average value of 4.07. Of all the statements (13 statements) provided, the media expert answered very well 4 times for a total of 20. Meanwhile, for statements with a weight of 4 as many as 6 times and for statements with a weight of 3 as many as 3 times. The grand total is 53 divided by the total number of statements equal to an average of 4.07. The table also shows that the results of the evaluation of linguists in general assess that the product developed falls into good criteria. This is indicated by the average value of 4.38 . Of all the statements (26 statements) provided, the linguist answered very well 10 times with a total of 50. Meanwhile, for statements weighing 4 as much as 16 times. The grand total is 114 divided by the total number of statements equal to a mean of 4.38 .

Table 2. The results of the product validation

\begin{tabular}{|c|c|c|c|c|}
\hline Validator & Indicators & Total & Average & Inf. \\
\hline Media & 13 & 53 & 4.07 & Good \\
\hline Language & 26 & 114 & 4.38 & Good \\
\hline
\end{tabular}

Table 3. The result of the implementation assessment on SIPADU

\begin{tabular}{|c|c|c|c|}
\hline Item & Respondent & Total & Average \\
\hline 20 & 78 & 1952 & 80.85 \\
\hline
\end{tabular}

\section{Implementation and Evaluation}

The assessment in the SIPADU implementation test was carried out by involving students as shadow tourists who directly used SIPADU. The implementation process did not only include the practice of using or utilizing SIPADU as a new platform for tourism promotion, but also, at this stage, they were asked to provide an assessment of the overall effectiveness and efficiency of the product. The results of the implementation can be seen in the table 3 .

Table 3, in general, shows that the result of the implementation regarding the appropriateness of the use of the SIPADU application is good, with an average score of 80.85 , with a comparison of $\geq 80$ values indicating B criteria (Good). Thus, it can be concluded that the SIPADU is suitable for the use as a medium for promoting the tourism destination in Madura. Evaluation as the next step in the development process was conducted by revising the product based on the expert critics and inputs for a better performance of the SIPADU. Those inputs are such as language improvement, layout enhancement, and additional features such as chat forum and search channel for amenities feature. All those inputs were completed in this final step.

Information technology has played an important role in tourism through flight ticket applications and hotel reservations (Gretzel et al., 2015), and the prevalence of Internet communication technology has significantly expanded the impact of IT on tourism (Li et al., 2017; Xiang, 2018; Yoo et al., 2017). This not only facilitates direct interaction with service providers but also greatly expands travel options for travelers (Ukpabi and Karjaluoto, 2017). The influence of IT on tourism is receiving more and more attention with the emergence of smart tourism. It helps travelers to expand their cognitive boundaries from trip planning with visualized destination details and improve decision quality with data-based and context-specific recommendations (Jung et al., 2015). Smart tourism is very different from previous e-tourism, which provided information via websites in the pre / post-travel phase, by offering smart technology-mediated tourism experiences through information, aggregation, ubiquitous connectivity and real-time synchronization. Smart tourism provides more relevant information, greater mobility, and better decision support for tourism (Yoo et al., 2017). It can be concluded that smart tourism destinations are knowledge-based destinations, where ICTs are used to provide technology platforms.

The use of smart tourism technologies such as travel-related websites, social media and smartphones in travel planning has spread and grown. Currently, most of the search for travel information and reservations and payments during the travel preparation stage is done via the Internet. Even during travel periods, the Internet, smartphones and other technologies provide rich, diverse and useful information to tourists due to their accessibility and easy connection (Sigala, 2018).

The increased availability of smartphones and mobile gadgets has transformed the tourism industry and will continue to improve the way tourists access information while traveling (Wang et al., 2014). Desk-based computer interaction that does not move through single-screen environments with little connectivity has been replaced by mobile and multi-connectivity multi-screen devices, delivering ubiquitous computing experiences (Huang et al., 2017; Jovicic, 2019; Li et al., 2017; Yoo et al., 2017). In the tourism industry, the upgrading of cell phones and smartphones has changed the way tourists collect and access information while on vacation (Buhalis and Law, 2008; Kiralova and Pavliceka, 2015). 
Traditionally, orientation at a destination was provided by tour guides, signposts, or online maps. However, the popularity of smartphones with built-in cameras, global positioning systems (GPS), and Internet connections has increased the availability of Augmented Reality applications (Jung et al., 2015) or Virtual Reality (Dorcic et al., 2019) which allows destinations to build personal, context-aware travel experiences.

\section{CONCLUSION}

The development of the SIPADU application through the concept of m-tourism based on Android using virtual reality as a tourism promotion strategy in Madura can be a solution for tourists in obtaining Madura tourism information including information about destinations, accommodation, amenities and tourism support facilities. In addition, SIPADU, for tourism stakeholders, can become a promotional media for the tourism industry in Madura and become an applicable medium for the development of Madurese tourism. To summarize, the SIPADU application through the concept of m-tourism based on android is feasible to be used and utilized as a medium of information as well as promotion of tourism in Madura.

Tourists who want to visit Madura, Indonesia are advised to take advantage of the SIPADU application as a tourism information media and for tourism stakeholders it is hoped that they can use the SIPADU application as a medium for accessing tourism information in Madura.

\section{Acknowledgments}

Special thanks to Universitas Negeri Malang for financial support on this research.

\section{REFERENCES}

Anamis, D.R., Umam, F., \& Rachma, A. (2017). Sistem informasi pencarian lokasi wisata di Kabupaten Jember berbasis multimedia [Multimedia-based tourist location search information system in Jember Regency]. SNATIKA, 4, 32-36.

Arifin, S. (2017). Digitalisasi pariwisata Madura [Digitalization of Madura tourism]. Komunikasi, XI (1), 53-60. http://dx.doi.org/10.21107/ilkom.v11i1.2835

Berne, C., Garcia-Gonzalez, M., \& Mugica, J. (2012). How ICT shifts the power balance of tourism distribution channels. Tourism Management, 33(1), 205-214. https://doi.org/10.1016/j.tourman.2011.02.004

Borràs, J., Moreno, A., \& Valls, A. (2014). Intelligent tourism recommender systems: A survey. Expert Systems with Applications, 41(16), 7370-7389. https://doi.org/10.1016/j.eswa.2014.06.007

Branch, R.M., \& Kopcha, T.J. (2014). Instructional design models: Handbook of research on educational communications and technology. Springer.

Budoya, CM., Kissake, MM., \& Mtebe, JS. (2019). Instructional design enabled Agile Method using ADDIE Model and Feature Driven Development method. International Journal of Education and Development Using Information and Communication Technology, 15(1), 35-54.

Buhalis, D., \& Law, R. (2008). Progress in information technology and tourism management: 20 years on and 10 years after the InternetThe state of eTourism research. Tourism Management, 29(4), 609-623. https://doi.org/10.1016/j.tourman.2008.01.005

Dorcic, J., Komsic, J., \& Markovic, S. (2019). Mobile technologies and applications towards smart tourism - state of the art. Tourism Review, 74(1), 82-103. https://doi.org/10.1108/TR-07-2017-0121

Du, Lew, D., \& Ng, P.T. (2016). Tourism and economic growth. Journal of Travel Research, 55(4), 54-64.

Fauzi, P. (2018, July). Ini Strategi Kemenpar Viralkan Pariwisata Indonesia di Luar Negeri [Ministry of Tourism's Strategy to Viralize Indonesian Tourism Abroad]. Detik Travel. https://travel.detik.com/travel-news/d-4132831/ini-strategi-kemenpar-viralkan-pariwisataindonesia-di-luar-negeri

Fermoso, A.M., Mateos, M., Beato, M.E., \& Berjón, R. (2015). Open linked data and mobile devices as e-tourism tools. A practical approach to collaborative e-learning. Computers in Human Behavior, 51, 618-626. https://doi.org/10.1016/j.chb.2015.02.032

Garcia, P.J.C., Rivero, M.S., \& Pulido, J.I. (2015). Does tourism growth influence economics development? Journal of Travel Research, 54(2), 206-221.

Gretzel, U., Sigala, M., Xiang, Z., \& Koo, C. (2015). Smart tourism: Foundations and developments. Electronic Markets, 25(3), 179-188. https://doi.org/10.1007/s12525-015-0196-8

Huang, C.D., Goo, J., Nam, K., \& Yoo, C.W. (2017). Smart tourism technologies in travel planning: The role of exploration and exploitation. Information \& Management, 54(6), 757-770. https://doi.org/10.1016/j.im.2016.11.010

Jannah, L.J., \& Idajati, H. (2018). Faktor-faktor yang mempengaruhi integrasi pengembangan kawasan wisata di Pulau Segitiga Emas Kabupaten Sumenep [The factors influence the integration of the development of tourism areas in the Golden Triangle Island of Sumenep Regency]. JURNAL TEKNIK ITS, 7(2), C131-C136.

Jovicic, D.Z. (2019). From the traditional understanding of tourism destination to the smart tourism destination. Current Issues in Tourism, 22(3), 276-282. https://doi.org/10.1080/13683500.2017.1313203

Jung, T., Chung, N., \& Leue, M.C. (2015). The determinants of recommendations to use augmented reality technologies: The case of a Korean theme park. Tourism Management, 49, 75-86. https://doi.org/10.1016/j.tourman.2015.02.013

Kemenpar. (2018). Laporan Akuntabilitas Kinerja Kementerian Pariwisata Tahun 2017 [Performance Accountability Report of Ministry of Tourism in 2017]. Kementerian Pariwisata.

Kim, N., Song, H., \& Pyun, J.H. (2016). The relationship among tourism, poverty, and economic development in developing countries: A panel data regression analysis. Tourism Economics, 22(6), 74-90.

Kiralova, A., \& Pavliceka, A. (2015). Development of social media strategies in tourism destination. Procedia - Social and Behavioral Sciences, 175, 358-366. https://doi.org/10.1016/j.sbspro.2015.01.1211

Li, Y., Hu, C., Huang, C., \& Duan, L. (2017). The concept of smart tourism in the context of tourism information services. Tourism Management, 58, 293-300. https://doi.org/10.1016/j.tourman.2016.03.014

Malia, E., \& Hanafi. (2018). Analisis partisipasi desa dalam mengembangkan potensi wisata Pantai 9 menuju visit Sumenep 2018 [Analysis of village participation in developing the tourism potential of Pantai 9 towards a visit to Sumenep 2018]. Conference on Innovation and Application of Science and Technology, 203-211.

Manzo, G.G. (2018). Economic Impact 2018. World Travel \& Tourism Council. World Travel \& Tourism Council, US.

Martin, J.L.E., Morales, N.M., \& Sinclair, M.T. (2008). The role of economic development in tourism demand. Tourism Economics, 14(4), 73-90. 
Moradmand, N., Datta, A., \& Oakley, G. (2014). The Design and Implementation of an Educational Multimedia Mathematics Software: Using ADDIE to Guide Instructional System Design. Computer Science, 4(1), 37-49.

Nurif, M., \& Sulastri, E. (2017). Analisis perubahan eksternal dalam pengembangan kawasan wisata bahari kepulauan Sapeken Madura dengan menggunakan pendekatan pemasaran wilayah [Analysis of external changes in the development of marine tourism areas in the Sapeken Madura archipelago using a regional marketing approach]. Jurnal Sosial Humaniora, 10(2), 137-149.

Prihaariantova, Q.T. (2017). Sistem informasi hotel dan pariwisata Kota Surakarta [Hotel and tourism information system in Surakarta]. Thesis. Universitas Muhammadiyah Surakarta.

Purnomo, A., Idris, I., \& Kurniawan, B. (2020). Understanding local community in managing sustainable tourism at Baluran National Park Indonesia. GeoJournal of Tourism and Geosites, 29(2), 508-520. https://doi.org/10.30892/gtg.29210-485

Rashidi, B., Fung, C., \& Vu, T. (2016). Android fine-grained permission control system with real-time expert recommendations. Pervasive and Mobile Computing, 32, 62-77. https://doi.org/10.1016/j.pmcj.2016.04.013

Rini, D.A.S., Pratikto, W.A., \& Sambodo, K. (2015). Identifikasi potensi kawasan sumberdaya pulau kangean Kabupaten Sumenep Madura sebagai kawasan wisata bahari [Identification of the potential resource area of Kangean Island, Sumenep Madura Regency as a marine tourism area]. Jurnal Kelautan, 8(2), 60-70.

Sanchez, M.C.R., Martinez-Romo, J., Borromeo, S., \& Hernandez-Tamames, J.A. (2013). GAT: Platform for automatic context-aware mobile services for m-tourism. Expert Systems with Applications, 40(10), 4154-4163. https://doi.org/10.1016/j.eswa.2013.01.031

Sigala, M. (2018). New technologies in tourism: From multi-disciplinary to anti-disciplinary advances and trajectories. Tourism Management Perspectives, 25, 151-155. https://doi.org/10.1016/j.tmp.2017.12.003

Styawan, B.A. (2018). Rancang bangun sistem informasi tempat pariwisata di Provinsi Jawa Timur berbasis Android [Design of information system for tourism places in East Java Province based on Android]. TEKNOLOGI, 1(6), 1-13.

Thompson, A. (2011). Terrorism and tourism in developed versus developing countries, tourism economics. Tourism Economics, 17(3), 693-700.

Ukpabi, D.C., \& Karjaluoto, H. (2017). Consumers' acceptance of information and communications technology in tourism: A review. Telematics and Informatics, 34(5), 618-644. https://doi.org/10.1016/j.tele.2016.12.002

Vichivanives, R., \& Ralangarm, S. (2015). Temple information retrieval system using quick response code via mobile application. Procedia Social and Behavioral Sciences, 197, 998-1005. https://doi.org/10.1016/j.sbspro.2015.07.292

Wahyuningtyas, N., Kodir, A., Idris, I., \& Islam, N. (2020). Accelerating tourism development by community preparedness on disaster risk in Lombok, Indonesia. GeoJournal of Tourism and Geosites, 29(2), 545-553. https://doi.org/10.30892/gtg.29213-488

Wahyuningtyas, N., Tanjung, A., Idris, I., \& Dewi, K. (2019). Disaster Mitigation on Cultural Tourism in Lombok, Indonesia. GeoJournal of Tourism and Geosites, 27(4), 1227-1235. https://doi.org/10.30892/gtg.27409-428

Wang, D., Xiang, Z., \& Fesenmaier, D.R. (2014). Adapting to the mobile world: A model of smartphone use. Annals of Tourism Research, 48, 11-26. https://doi.org/10.1016/j.annals.2014.04.008

Xiang, Z. (2018). From digitization to the age of acceleration: On information technology and tourism. Tourism Management Perspectives, 25, 147-150. https://doi.org/10.1016/j.tmp.2017.11.023

Yoo, C.W., Goo, J., Huang, C.D., Nam, K., \& Woo, M. (2017). Improving travel decision support satisfaction with smart tourism technologies: A framework of tourist elaboration likelihood and self-efficacy. Technological Forecasting and Social Change, 123, 330-341. https://doi.org/10.1016/j.techfore.2016.10.071

Article history: Received: 27.11.2020 Revised: 22.02.2021 Accepted: 02.04.2021 Available online: 26.04.2021

